\title{
NOTE ON A SIMPLE MEANS FOR INCREASING CERTAINTY OF PERCEPTION OF COLOUR CHANGE IN VARIOUS TITRATIONS.
}

By A. Dupre, Ph.D., F.R.S.

Read before the Society of Public Analysts, on 2nd June, 1880.

As is well known, the change from pale yellow to red, in the titration of chlorides by means of nitrate silver with neutral chromate as indicator, is more distinctly perceived by gaslight than by daylight. No doubt eyes differ in regard to their power of perceiving slight variation of colour tint, and in my case I have always found it advisable, in the analysis of potable waters, containing from one to two grains of chlorine per gallon, considerably to concentrate by evaporation previous to titration, or else to perform the tritation by gaslight. The adoption of the following simple plan enables us, howerer, to perceive the change of colour as sharply and with as great a certainty by daylight as by gaslight.

The water is placed into a white porcelain dish (100 c.c. are a useful quantity), a moderate amount of neutral chromate is added (sufficient to impart a marked yellow colour to the water), but instead of looking at the water directly a flat glass cell containing some of the neutral chromate solution is interposed between the eje and the dish. The effect of this is to neatralize the yellow tint of the water, or, in other words, if the concentration of the solution in the cell is even moderately fairly adjusted to the depth of tint imparted to the water, the appearance of the latter, looked at through the cell, is the same as if the dish 
were filled with pure water. If now the standard silver solution is run in, still looking through the cell, the first faint appearance of a red colouration becomes strikingly manifest, and what is more, when once the correct point has been reached the eye is never left in doubt however long we may be looking at the water. A check experiment in which the water with just a slight deficiency of silver, or excess of chloride, is used for comparison is therefore unnecessary. The plan is useful chiefly with very dilute solutions, one or two grains of chlorine per gallon, and since I have adopted it I have entirely given up the concentration of the water prior to titration formerly practised.

A similar plan will, I think, be found useful in other titrations. Thus, in the case of turmeric, the change from yellow to brown is perceived more sharply and with greater certainty when looking through a flat cell containing tincture of turmeric of suitable concentration than with the naked eye. The liquid to be titrated should, as in the former case, be placed into a white porcelain dish. Again, in estimating the amount of carbonate of lime in a water by means of decinormal sulphuric acid and cochineal, the exact point of neutrality can be more sharply fixed by looking through the cell filled with a cochineal solution. In this case, the following is the plan I have found to answer best. The water to be tested-about 250 c.c.-is placed into a flat porcelain evaporating dish, part of which is covered over with a white porcelain plate. The water is now tinted with cochineal as usual, and the sulphuric acid run in, the operator looking at the dish through the cell containing the neutral cochineal solution. At first, the tint of the water and the tint in which the porcelain plate is seen are widely different; as, however, the carbonate becomes gradually neutralized, the two tints approach each other more and more, and when neutrality is reached they appear identical; assuming that the strength of the cochineal solution in the cell, and the amount of this solution added to the water, have been fairly well matched. Working in this manner I have found no difficulty (taking $\frac{1}{4}$ litre of water) to come within 0.1 c.c. of decinormal acid in two successive experiments, and the difference need never exceed 0.2 c.c. In the cell I employ, the two glass plates are a little less than half-an-inch apart.

A somewhat similar plan may be found useful in other titrations, or in fact in many operations depending on the perceptions of colour change. 